\title{
Pakkausten ympäristövaikutukset elintarvikeketjussa
}

\author{
Frans Silvenius1), Juha-Matti Katajajuuri1), Kaisa Grönman2), Risto Soukka2), Heta- \\ Kaisa Koivupuro1) and Yrjö Virtanen1)
}

\begin{abstract}
1 )MTT Maa- ja elintarviketalouden tutkimuskeskus, Biotekniikka- ja elintarviketutkimus, Kestävä biotalous, MTT (BEL), Latokartanonkaari 9, 00790 Helsinki, Finland, e-mail frans.silvenius@ mtt.fi
\end{abstract}

\section{2) Lappeenrannan teknillinen yliopisto, PL 20, 53851 Lappeenranta}

\section{Tiivistelmä}

FutuPackEKO2010-hankkeessa tutkittiin pakattujen elintarvikkeiden ja niiden erilaisten pakkausvaihtoehtojen ympäristövaikutuksia. Asiaa lähestyttiin kolmen elinkaaritapaustutkimuksen avulla. Monista aiemmista elintarvikkeiden ympäristövaikutustutkimuksista poiketen myös kotitalouksissa mahdollisesti syntyvä tuotehävikki ja sitä kautta turhasta elintarviketuotannosta ja jätehuollosta aiheutuvat ympäristövaikutukset sisällytettiin tutkimuksessa laadittuihin tuotepakkausyhdistelmien elinkaariarviointeihin. Yksi keskeinen selvitettävä tekijä oli arvioida hävikiksi päätyvän tuoteosuuden tuotannosta aiheutuvien ympäristövaikutusten merkittävyyttä suhteessa itse pakkausten valmistamisen ja loppukäytön ympäristövaikutuksiin.

Tutkimukseen valitut elintarviketuotteet olivat ruispalaleipä, soijapohjainen jogurttityyppinen tuote (Soygurt) ja kokolihaleikkele useilla eri pakkauskoko- ja materiaalivaihtoehdoilla. Ympäristövaikutustarkastelussa huomioitiin kyseisten tuotteiden koko tuotanto- ja kulutusjärjestelmissä syntyvät vaikutukset mukaan lukien alkutuotannon panostuotanto, alkutuotanto, prosessointi, kauppa ja kuljetukset. Lisäksi huomioitiin kotitalouksissa ylijäävän elintarvikejakeen eli kotitaloushävikin tuotannosta ja jätehuollosta aiheutuvat ympäristövaikutukset. Ympäristövaikutusluokista huomioitiin ilmastonmuutos, rehevöityminen ja happamoituminen sekä kaatopaikkajätteen määrä.

Kotitalouksissa syntyvää ruokahävikkiä erikokoisilla pakkauksilla tutkittiin kuluttajakyselyllä. Kyselyn tuloksena saadut hävikit jäivät kuitenkin kohtalaisen pieniksi suhteessa muualla maailmassa esitettyihin lukuihin eikä eri pakkausvaihtoehtojen hävikeissä havaittu juurikaan merkittäviä eroja, joten kotitaloushävikkiä mallinnettiin kyselyn tulosten lisäksi erilaisilla hävikkiskenaarioilla. Pakkausten ja kotitaloushävikin loppukäsittely mallinnettiin neljän eri jätehuoltotilanteen mukaan, joista kaksi kuvasivat nykyään käytössä olevia sekajätteen ja biojätteen käsittelytapoja.

Tulokset osoittavat, että itse kyseisten elintarviketuotteiden tuotannosta syntyvät ympäristövaikutukset ovat tuote-pakkausjärjestelmätasolla määräävä tekijä. Kotitaloushävikin määrän havaittiin olevan tutkimukseen valituilla hävikkiskenaarioilla pääsääntöisesti tärkeämpi ilmastonmuutokseen, rehevöitymiseen ja happamoitumiseen vaikuttava tekijä kuin tuotetta suojaavien pakkausten valmistus ja loppukäyttö. Pakkausratkaisut ja -muodot, joilla kotitaloushävikkiä syntyi mahdollisimman vähän, aiheuttivat täten kokonaisuudessaan myös vähiten ympäristövaikutuksia. Siksi kotitalouksissa syntyvän ruokahävikin määrä ja sen tuotannosta ja käsittelystä syntyvät ympäristövaikutukset olisi ehdottomasti arvioitava yhtenä elintarvikepakkausten suunnittelussa huomioitavana tekijänä ja tuotteiden ja pakkausten tutkimuksen ja tuotekehityksen tulisi tapahtua rinnakkain. Erot tutkittujen erilaisten pakkausmateriaalien ympäristövaikutuksissa osoittautuivat pieniksi.

Avainsanat: Elinkaariarviointi, pakkaukset, ympäristövaikutukset, elintarvikkeet, hiilijalanjälki

\section{Johdanto}


Pakkauksiin liittyy useita myyttejä, jotka voivat vaikuttaa kuluttajavalintoihin. Monet kuluttajat pitävät pakkauksia merkittävänä ympäristökysymyksenä, ja ajattelevat, että pakkaussuunnittelussa on tärkeää minimoida pakkausmateriaalin määrä tuoteyksikköä kohden ja suosia näin ollen suurempia pakkauskokoja.

Elintarvikepakkauksilla on kuitenkin monia tärkeitä tehtäviä: pakkausten tulee suojata tuotetta ja täten mahdollistaa sen toimittaminen kuluttajalle ensiluokkaisessa kunnossa sekä tarjota kuluttajalle tuoteinformaatiota. Pakkauksen rooli pakattavan tuotteen suojaajana ja pakkauskoon ja -materiaalin vaikutus tuote- pakkaussysteemin kokonaisympäristövaikutuksiin olivat tässä tutkimuksessa keskeisiä lähtökohtia.

Elintarvikkeita koskevissa aiemmissa ympäristövaikutustutkimuksissa on vastoin edellä mainittuja myyttejä havaittu, että useissa tapauksissa pakkauksen valmistuksen osuus tuotteen ympäristövaikutuksista on suhteellisen vähäinen (Katajajuuri et al. 2003; Katajajuuri ja Virtanen 2007). Tämä on kuitenkin todettu vaihtelevan tapauskohtaisesti riippuen pakattavasta elintarvikkeesta ja valitusta pakkausvaihtoehdosta. Useimmissa aiemmissa pakkausten ympäristövaikutustarkasteluissa ei ole otettu huomioon itse tuotteen tuottamisen eikä kotitalouksissa mahdollisesti syntyvän tuotehävikin ympäristövaikutuksia (Silvenius et al. 2011), ja tämä artikkeli käsittelee siten uutta tutkimusnäkökulmaa, jossa kyseiset kaksi asiaa yhdistetään.

Aihetta lähestyttiin tutkimalla kolmea esimerkkituotetta, ja tavoitteena oli laskea ympäristövaikutukset kyseisille elintarviketuotteille ja niiden erilaisille pakkauskoko- ja materiaalivaihtoehdoille. Tuotteet olivat ruispalaleipä, kokolihaleikkele ja Soygurt soijapohjainen fermentoitu jogurttityyppinen tuote. Tavoitteena oli havainnollistaa elintarviketuotteiden koko elinkaaren alueelta kertyviä ympäristövaikutuksia erilaisten pakkausmateriaalien ja pakkauskokojen sekä pakkauksen jätteenkäsittelyvaihtoehtojen variaatioiden funktiona.

\section{Aineisto ja menetelmät}

Tutkimuksessa selvitettiin kohteina olevien tuotteiden ja niiden pakkausvaihtoehtojen tuotannosta ja kulutuksesta aiheutuvat kasvihuonekaasu- (hiilijalanjälki), rehevöittävät ja happamoittavat päästöt. Päästöjen merkittävyys ympäristövaikutusten kannalta määriteltiin käyttämällä yleisesti käytössä olevia karakterisointikertoimia, joiden avulla kyseiset päästöt saatiin muunnettua vaikutusluokittain yhteismitallisiksi (Solomon ym. 2007 Seppälä ym. 2004 Seppälä ym. 2006).

Tutkimuksen toiminnallinen yksikkö oli jokaisessa tapaustutkimuksessa 1000 kg kuluttajan nauttimaa lopputuotetta. Kaikkien tutkittavien tuotantoketjujen rajauksiin sisältyvät kotitalouksissa syntyvä tuotehävikki eli kotitaloushävikki, tuotejakelu, vähittäiskauppa, tuotteen valmistusprosessi, raaka-aineiden valmistusprosessit ja viljely, maatalouden panostuotanto, pakkausten ja niiden raakaaineiden tuotanto ja valmistus ja erilaiset jätehuolto- ja hyödyntämisvaihtoehdot ja kaikki ketjun eri vaiheissa tapahtuvat kuljetukset. Tutkimuksen ulkopuolelle jätettiin kaikissa tapaustutkimuksissa rakenteiden ja työkoneiden valmistusprosessit, torjunta-aineiden käyttö viljelyssä sekä kuluttajien kauppamatkat, ruoan säilytys ja valmistus kotitalouksissa ja eri tuotantoketjun vaiheisiin liittyvät työntekijöiden työmatkat, lukuun ottamatta mustikoiden keruuseen liittyvää matkustamista. Energiankulutuksista sähköenergian tuotannossa käytettiin valtakunnallisia päästökertoimia ja lämpöenergian ja kaukolämmön tuotannossa voimalakohtaisia päästökertoimia.

Tarkastellut pakkausvaihtoehdot jokaiselle tapaustutkimukselle on esitetty taulukossa 1. Tapaustutkimus Soygurtin vaihtoehdon 1 pakkausvaihtoehto on 0,75 litran nestepakkauskartonki, joka sisältää muovisen uudelleensuljettavan avausmekanismin. Pakkausvaihtoehto 2 on $150 \mathrm{ml}: \mathrm{n}$ polypropeenipikari alumiinikannella.

Ruispalaleivän pakkausvaihtoehtoina olivat polypropeeni, polyeteeni ja polyeteenipinnoitettu paperipussi, jossa on polypropeeni-ikkuna (Taulukko 1). Kaikki pussivaihtoehdot suljetaan klipsisulkimella, jossa on teräslanka ja polypropeenia. 
Taulukko 1: Pakkausvaihtoehdot

\begin{tabular}{|c|c|c|c|c|}
\hline \multicolumn{5}{|c|}{ Soygurt (soijapohjainen jogurttityyppinen tuote), kaksi pakkausvaihtoehtoa } \\
\hline $\begin{array}{l}\text { Kuluttaja- } \\
\text { pakkaus }\end{array}$ & \multicolumn{2}{|c|}{$\begin{array}{l}\text { Nestepakkauskartonki, joka sisältää } \\
\text { alumiinia ja polyeteeniä sekä muovisen } \\
\text { uudelleensuljettavan avausmekanismin }\end{array}$} & \multicolumn{2}{|c|}{ Polypropeenipikari alumiinikannella } \\
\hline Pakkauskoko & \multicolumn{2}{|l|}{$750 \mathrm{ml}$} & \multicolumn{2}{|l|}{$150 \mathrm{ml}$} \\
\hline Kuljetuspakkaus & \multicolumn{2}{|l|}{ Aaltopahvi $69 \mathrm{~g}$} & \multicolumn{2}{|l|}{ Aaltopahvi $47 \mathrm{~g}$} \\
\hline $\begin{array}{l}\text { Pakkauksia } \\
\text { kuljetuspak- } \\
\text { kauksesa }\end{array}$ & \multicolumn{2}{|l|}{10} & \multicolumn{2}{|l|}{5} \\
\hline \multicolumn{5}{|c|}{ Ruispalaleipä, neljä pakkausvaihtoehtoa } \\
\hline $\begin{array}{l}\text { Kuluttaja- } \\
\text { pakkaus }\end{array}$ & Polypropeeni(PP) & Polypropeeni(PP) & Polyeteeni(PE) & $\begin{array}{l}\text { Paperi/PE PP- } \\
\text { ikkunalla }\end{array}$ \\
\hline Pakkauskoko & $500 \mathrm{~g}$ & $220 \mathrm{~g}$ & $500 \mathrm{~g}$ & $500 \mathrm{~g}$ \\
\hline Kuljetuspakkaus & $\begin{array}{l}\text { kiertävä PE- } \\
\text { laatikko }\end{array}$ & $\begin{array}{l}\text { kiertävä PE- } \\
\text { laatikko }\end{array}$ & $\begin{array}{l}\text { kiertävä PE- } \\
\text { laatikko }\end{array}$ & $\begin{array}{l}\text { kiertävä PE- } \\
\text { laatikko }\end{array}$ \\
\hline \multicolumn{5}{|c|}{ Kokolihaleikkele, kuusi pakkausvaihtoehtoa } \\
\hline $\begin{array}{l}\text { Kuluttaja- } \\
\text { pakkaus }\end{array}$ & $\begin{array}{l}\mathrm{PP} / \mathrm{PE} / \mathrm{PA} / \mathrm{EVOH} \\
\text { (alakalvo) } \\
\mathrm{PP} / \mathrm{PE} / \mathrm{EVOH} \\
\text { (yläkalvo) }\end{array}$ & $\begin{array}{l}\text { kartonki/PE/EVOH } \\
\text { (alakalvo) } \\
\text { PP/PE/EVOH } \\
\text { (yläkalvo) }\end{array}$ & $\begin{array}{l}\text { APET/EVOH/PE } \\
\text { (alakalvo) } \\
\text { PE/EVOH/PET } \\
\text { (yläkalvo) }\end{array}$ & $\begin{array}{l}\text { APET/EVOH/PE } \\
\text { (alakalvo) } \\
\text { PE/EVOH/OPET } \\
\text { (yläkalvo) }\end{array}$ \\
\hline Pakkauskoko & $300 \mathrm{~g}$ ja $150 \mathrm{~g}$ & $300 \mathrm{~g}$ ja $150 \mathrm{~g}$ & $300 \mathrm{~g}$ & $150 \mathrm{~g}$ \\
\hline Kuljetuspakkaus & $\begin{array}{l}\text { kiertävä PE- } \\
\text { laatikko }\end{array}$ & $\begin{array}{l}\text { kiertävä PE- } \\
\text { laatikko }\end{array}$ & $\begin{array}{l}\text { kiertävä PE- } \\
\text { laatikko }\end{array}$ & $\begin{array}{l}\text { kiertävä PE- } \\
\text { laatikko }\end{array}$ \\
\hline
\end{tabular}

Kokolihaleikkeleen ensimmäinen pakkausvaihtoehto koostuu ylä- ja alaradasta, jotka on valmistettu polypropeeniä sisältävistä monikerrosmuovikalvoista. Toisessa pakkausvaihtoehdossa on sama ylärata, mutta alaratana on päällystettyä kartonkia. Kolmantena vaihtoehtona tarkasteltiin monikerrosratkaisua, jossa on käytetty polyeteenitereftalaattia. Jokaisesta kolmesta pakkausvaihtoehdosta tarkasteltiin sekä $150 \mathrm{~g}$ että $300 \mathrm{~g}$ pakkauskokoa.

Ympäristövaikutustenarviointi tehtiin elinkaariarviointimenetelmällä (Life Cycle Assessment, LCA). Elinkaariarvioinnissa noudatettiin siitä annettuja standardeja ISO 14040 ja ISO 14044. Tutkimus tehtiin "Attributional"- eli haitanjako-lähestymistavalla, jossa kohdennetaan ja allokoidaan panoksia ja tuotoksia eri tuotteille. "Attributional"-lähestymistapaan tehtiin poikkeus pakkausmateriaalien hyötykäytön mallinnuksessa, jossa laskettiin pakkausjärjestelmille päästöhyvityksiä, koska tämä katsottiin parhaaksi keinoksi ottaa tarkasteluissa huomioon pakkausten energiahyötykäytöstä saatavan energia.

Ruispalaleivän, kokolihaleikkeleen ja Soygurtin tuotantoprosessissa käytettiin tuotteiden tuotantolaitoksista saatua primaaridataa. Samoin tuotantoketjukohtaista tietoa saatiin muovipakkausten sekä paperipussin ja kokolihaleikkeleen kartonkiosan konvertointiprosessista (tuotantolaitostasolla), viljaraaka-aineiden jauhatuksesta, soijapitoisen juoman raaka-aineiden prosessoinnista sekä teurastamotoiminnasta. Kotimaisen rukiin ja vehnän valmistuksesta käytettiin lannoitteiden, kalkin kulutuksen ja satotason osalta keskimääräisiä suomalaista dataa (Pro Agria) ja maataloustoiminnoista polttoaineenkulutuksen osalta erilaisia malleja ja viljelyyn liittyvien typpioksiduuli- ja ammoniakkipäästöjen osalta IPCC:n laskentaohjeistuksia. Soijanviljelystä saatiin tietoja 
yhdysvaltalaiselta toimittajalta. Pakkausmateriaaleista polypropeenin, polyeteenin, polyeteenitereftalaatin, aaltopahvin ja alumiinin osalta käytettiin tietokantatietoja.

Kotitalouksissa syntyvää ruokahävikkiä tutkittiin kuluttajakyselyllä, jonka tavoitteena oli selvittää, kuinka paljon ruokahävikkiä keskimäärin syntyy eri elintarviketuoteryhmissä ja miten pakkauskoko vaikuttaa hävikin määrään eri tuoteryhmissä. Soijapohjaisen tuotteen osalta tehtiin myös tyhjennyskokeita, jolla määritettiin tyhjennettyyn pakkaukseen keskimäärän jäävän tuotteen määrä. Kyselyn tuloksena saadut hävikit jäivät kohtalaisen pieniksi suhteessa muualla maailmassa esitettyihin lukuihin. Lisäksi eri pakkausvaihtoehdoista syntyvissä hävikkimäärissä ei havaittu juurikaan merkittäviä eroja. Hävikin syntymäärien arviointi on kuluttajille hyvin vaikeaa ja kyselyn tuloksena saatuja ruokahävikkiprosentteja voitiinkin pitää vain karkeina arvioina kyseisten tuotteiden hävikeistä kotitalouksissa. Elinkaariarviointilaskelmissa käytettiin kuluttajakyselyyn ja aiheesta muualla tehtyihin tutkimuksiin perustuvia ruokahävikkiskenaarioita (mm. WRAP 2008)

Jätehuolto mallinnettiin neljällä jätehuoltoskenaariolla, joista toisella nykytilaa kuvaavalla skenaariolla käsiteltiin tilannetta, jossa ei ole jätteiden energiahyötykäyttömahdollisuutta. Sekajäte sijoitetaan kaatopaikalle, kuitupakkauksista osa kierrätetään ja osa loppusijoitetaan kaatopaikalle. Elintarvikkeista kokolihaleikkele ja ruispalaleipä kompostoidaan suurelta osalta, loppu ruokahävikistä päätyy kaatopaikalle. Soygurt oletettiin päätyvän pakkauksen pohjalla kokonaan kaatopaikalle.

Toisessa nykytilaskenaariossa kuvattiin energiajätteen hyötykäyttötilannetta, jossa jätteillä on energiahyötykäyttömahdollisuus. Sekajäte oletettiin menevän pääsääntöisesti energiahyötykäyttöön ja kuitupakkaukset suurelta osin materiaalikierrätykseen, osa energiahyötykäyttöön ja osa kaatopaikalle. Kokolihaleikkele ja ruispalaleipä oletettiin kompostoitavaksi suurelta osalta, loppu kuluttajahävikistä päätyy kaatopaikalle. Tässä mallissa oletetaan, että kuluttaja huuhtelee viemäristä alas Soygurt-jäämät, jolloin ne päätyvät jäteveden käsittelyyn. Lisäksi mallinnus suoritettiin kahdella jätehuoltoskenaariolla, joista toinen kuvasi kaikkien jätejakeiden johtamista massapolttoon ja toinen maksimaalista kierrätystä ja energiahyötykäyttöä.

\section{Tulokset ja niiden arviointi}

Tulokset osoittavat, että itse kyseisten elintarvikkeiden tuotantoketjut aiheuttivat tuotepakkausjärjestelmätasolla selvästi eniten ympäristövaikutuksia. Lisäksi havaittiin, että kotitalouksissa syntyvästä tuotehävikistä johtuva elintarvikkeiden turha tuottaminen kuormittaa ympäristöä pääsääntöisesti enemmän kuin pakkausten valmistus ja jätehuolto (Taulukko 2).

Taulukko 2: Pakkausten osuus ja arvioidun kotitalouksien ruokahävikin ympäristövaikutuksen sekä jätehuollon osuus tutkittujen tuotteiden kokonaisympäristövaikutuksista

\begin{tabular}{|l|l|l|l|l|}
\hline & Ruispalaleipä & Kokolihaleikkele & $\begin{array}{l}\text { Soygurt, NP- } \\
\text { kartonki }\end{array}$ & Soygurt, Muovipikari \\
\hline $\begin{array}{l}\text { Pakkausten } \\
\text { tuotanto }\end{array}$ & $2-3 \%$ & $1-2.5 \%$ & $5-6 \%$ & $10-13 \%$ \\
\hline $\begin{array}{l}\text { Jätehuolto } \\
\begin{array}{l}\text { Kotitaloushävikin } \\
\text { tuotanto }\end{array}\end{array}$ & $0-3 \%$ & $0-1,5 \%$ & $0,5-7 \%$ & $1,5-4,5 \%$ \\
\hline Ruoan tuotanto & $71-98 \%$ & $0-16 \%$ & $5-11 \%$ & $2-6 \%$ \\
\hline
\end{tabular}

Kokolihaleikkeleessä tuotteen valmistus dominoi kaikkia ympäristövaikutuksia (Kuva 1.). Pakkauksen valmistamisen osuus on 1-3\% hiilijalanjäljestä ja niiden jätehuollon 0,5-2 \% hiilijalanjäljestä, joten kuluttajahävikin osuus on merkittävämpi, ollen suuremmalle pakkauskoolle $0-8 \%$ hiilijalanjäljestä ja pienemmälle pakkauskoolle $0-15 \%$ hiilijalanjäljestä. Kuvasta 1 näkyy, että jos pienemmällä 
pakkauskoolla päästään nollahävikkiin, on kokonaishiilijalanjälki pienempi kuin suuremman pakkauskoon hiilijalanjälki vähintään yhden kinkkuviipaleen kuluttajahävikillä. Eri pakkausmateriaalien väliset erot tuote-pakkaus-yhdistelmän kokonaisympäristövaikutuksiin nähden, olivat vähäisiä, jos kotitaloushävikki on sama.

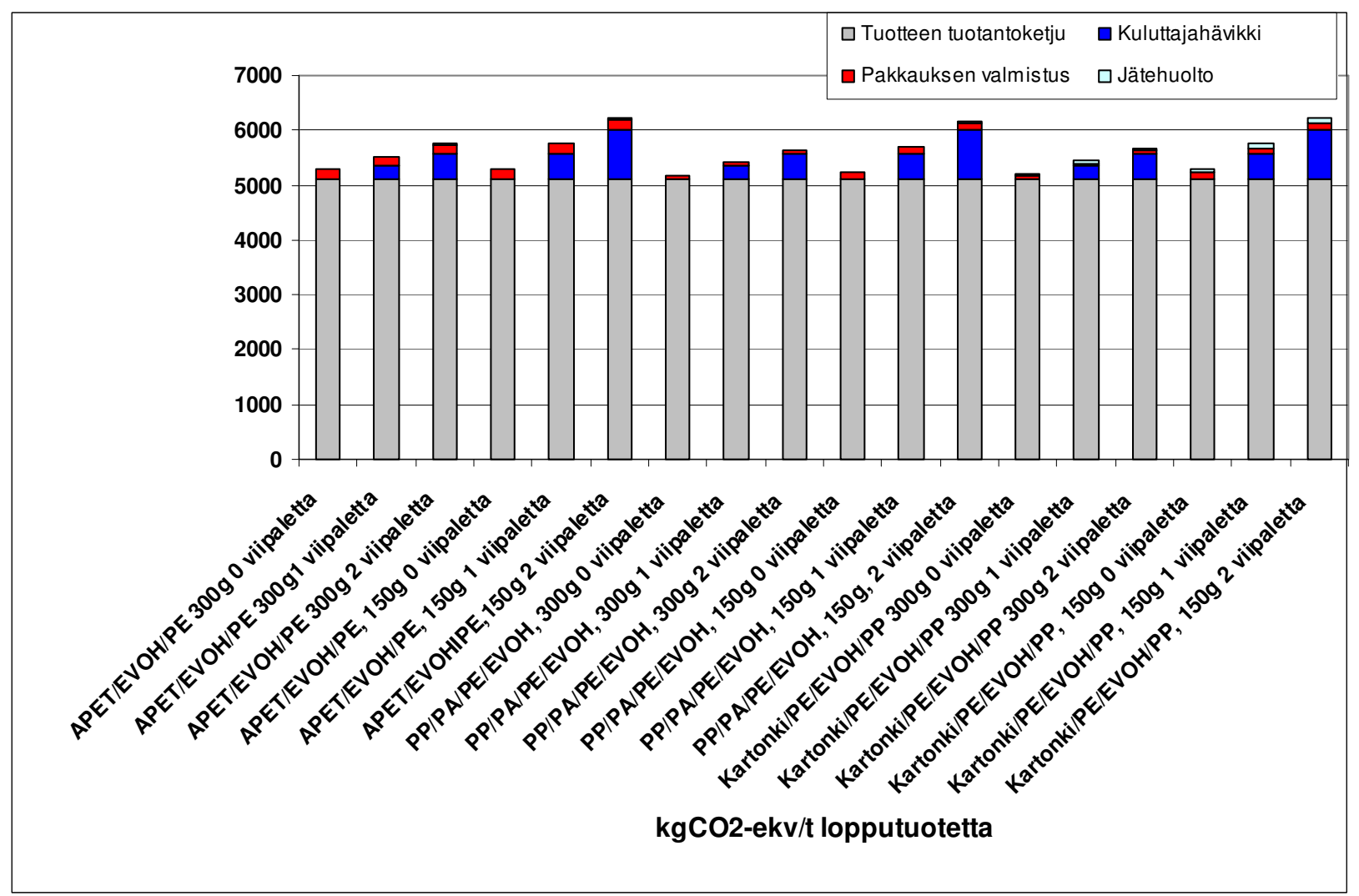

Kuva 1. Kokolihaleikkeleen tuotantoketjun ilmastovaikutukset jaoteltuna komponentteihin. Loppukäyttöskenaariona sekajätteelle kaatopaikkakäsittely.

Kuva 2 havainnollistaa vielä enemmän kotitalouksien ruokahävikin merkittävyyttä suhteessa pakkausten valmistamiseen. Jos neljän leivän pakkauskoolla pääsee nollahävikkiin, ovat kokonaisympäristövaikutukset pienemmät kuin suuremman pakkauskoon puolen leipäviipaleen hävikillä. Pakkausmateriaalien erot ovat myös tässä vertailussa pienet, kun hävikkiskenaario on sama.

Myös esimerkkitapausten rehevöittäviä ja happamoittavia päästöjä laskettaessa päädyttiin siihen, että itse tuotteen tuotantoketjulla oli suurin merkitys tuote-pakkausyhdistelmän ympäristövaikutuksiin. Erityisesti kokolihaleikkeleen ja ruispalaleivän rehevöittävissä päästöissä pakkausten ja niiden jätehuollon merkitys oli pieni suhteessa kotitalouksien hävikkiin. 


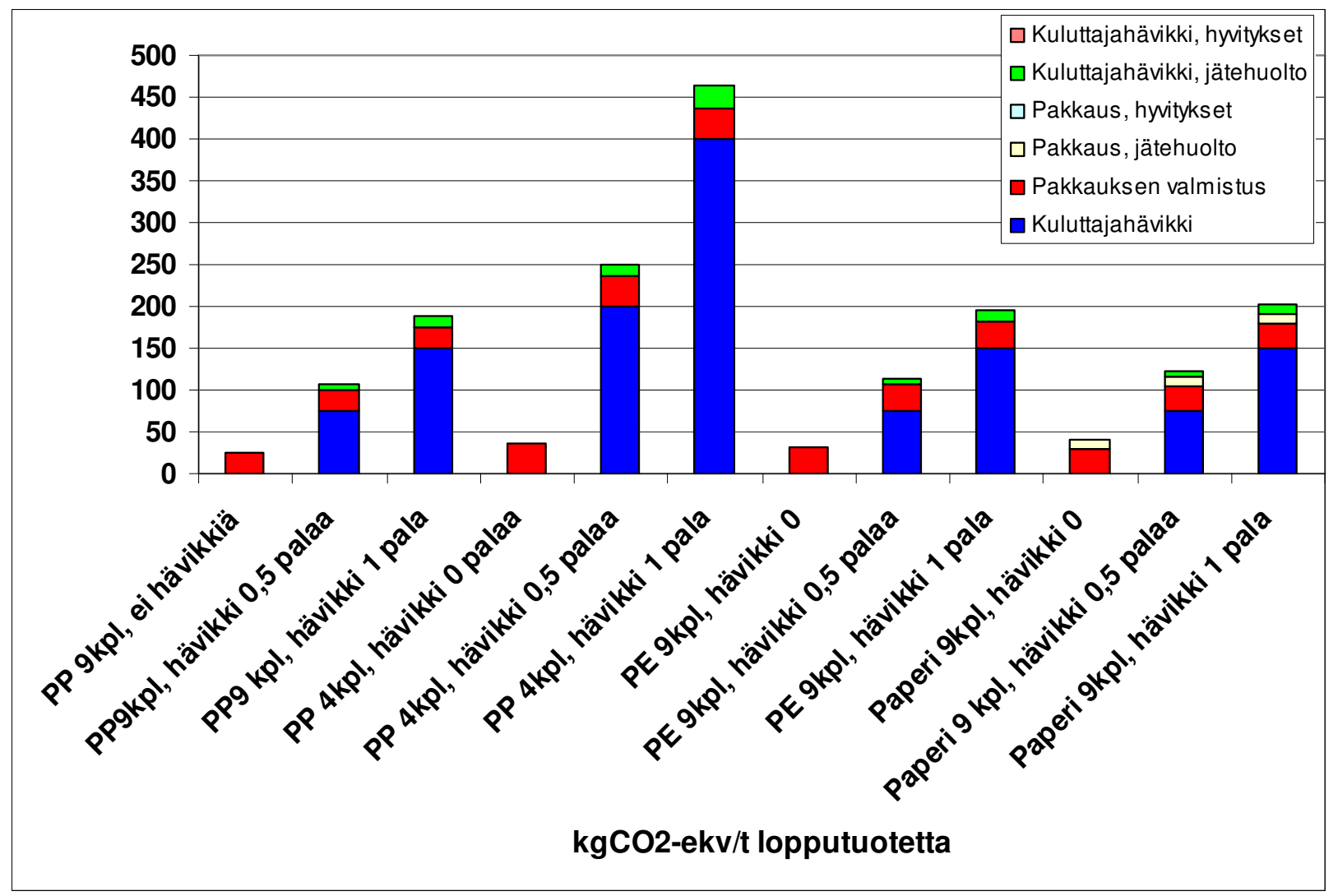

Kuva 2. Kotitalouksissa hävikiksi päätyneen ruispalaleivän ja sen neljän pakkausvaihtoehdon tuotannon ja jätehuollon kasvihuonekaasupäästöt erilaisilla kotitaloushävikkiskenaarioilla. Jätteenkäsittelyvaihtoehtona sekajätteelle kaatopaikkakäsittely.

\section{Johtopäätökset}

Elintarvikkeiden valmistus dominoi tutkittujen tuote- pakkausyhdistelmien ympäristövaikutuksia. Pakkausten valmistuksen ja niiden jätehuollon osuus elinkaaren aikaisista ympäristökuormituksista oli useissa tapauksissa vain muutamia prosentteja koko tuote-pakkausjärjestelmän vaikutuksista. Myös rehevöittävissä ja happamoittavissa päästöissä pakkausten osus oli samaa suuruusluokkaa. Kuitenkin Soygurtin tapauksessa pakkausten valmistuksen osuus oli 5-10\% kokonaisilmastovaikutuksesta ja jopa 12-23 \% happamoittavista päästöistä. Tämä johtui siitä, että tuote sisälsi paljon vettä ja siitä, että pakkausmateriaalia tarvittiin tuotepainoa kohden enemmän kuin esim. ruispalaleipään. Kotitalouksissa hävikkiin päätyneen tuotemäärän tuotantoketjun osuus ilmastovaikutuksista vaihteli välillä 0-26\% tutkimuksessa käytetyillä kotitaloushävikkiskenaarioilla. Kyseisillä hävikkiprosenteilla kuluttajalta syntyvän tuotehävikin osuus tuotteen ympäristökuormituksesta oli useimmiten suurempi kuin itse pakkauksen valmistuksen osuus. Muovipakkaukset eivät hajoa kaatopaikalla synnyttäen hiilijalanjälkeä nostavia metaanipäästöjä, mutta sen sijaan niiden käyttö lisää kaatopaikoilla tai luonnossa hajoamattomien jätteiden määrää. Tämän tutkimuksen oletusten perusteella leikkeleen ja ruispalojen kuitupakkausten materiaalista ei tarkasteluajanjakson (100 vuotta) aikana kuitenkaan hajoa kuin alle kolmannes.

Pakkausten valmistamisen ja loppukäytön synnyttämät rehevöittävät ja happamoittavat päästöt ovat tämän tutkimuksen tulosten perusteella yleensä suhteellisen pieniä verrattuna kuluttajilta syntyneestä tuotehävikistä aiheutuviin päästöihin. Happamoittavissa päästöissä pakkauksen valmistuksen merkitys oli merkittävä Soygurt-tapaustutkimuksessa, mutta myös happamoittavia päästöjä pystytään vähentämään oleellisesti ottamalla pakkaussuunnittelussa huomioon tuotehävikin, erityisesti kotitaloushävikin minimointi. 
Tutkimustulosten mukaan pakkaussuunnittelussa pystytään parhaiten vähentämään rehevöittäviä, happamoittavia ja kasvihuonekaasupäästöjä pyrkimällä kuluttajilta syntyvän hävikin minimointiin. Pakkauksia suunniteltaessa olisi pyrittävä sellaisiin pakkausratkaisuihin koon, muodon ja muiden ominaisuuksien suhteen, että pakkaus säilyttäisi ja suojaisi tuotetta tehokkaasti ja pitkään sekä tarjoaisi kuluttajalle sopivan määrän tuotetta minimoiden täten kotitalouksissa syntyvän tuotehävikin. Yksittäisistä tapaustutkimustuloksista ei voida esimerkiksi päätellä mitään siitä, mitä materiaalia vähiten kuormittavat pakkaukset ovat ja jokaisella pakkausmateriaalilla on käyttökohteesta riippuen omat hyvät ja huonot puolensa.

Tuotejärjestelmän eri vaiheissa syntyvän tuotehävikin arvioidut ympäristövaikutukset tutkittaessa pakkaus-tuote-yhdistelmän ympäristövaikutuksia tulisi huomioida, ainakin hävikkiskenaarioiden kautta. Tutkimustuloksista käy selvästi ilmi se, että mikäli tutkituilla pienemmillä pakkauskoilla kotitalouksien ruokahävikki saadaan vähennettyä nollaan ja suuremmalla pakkauskoolla kotitaloushävikki on yli 5\%, oli pienempi pakkauskoko tällöin ympäristöystävällisempi. Tutkimuksen yksi pääasiallisista johtopäätöksistä onkin, että tutkittaessa ja vertaillessa erilaisten pakkausten ympäristövaikutuksia, vertailuihin tulee ehdottomasti sisällyttää tuotteiden ja sitä kautta tuotejärjestelmän eri vaiheissa syntyvän tuotehävikin arvioidut ympäristövaikutukset, ainakin hävikkiskenaarioiden kautta.

Vain tällaisella lähestymistavalla saadaan kokonaiskuva verrattavista asioista ja niiden suuruusluokista. Kotitalouksien ruokahävikkejä selvittäneen kuluttajakyselyn tulosten perusteella ei kuitenkaan voitu havaita merkittäviä eroja saman tuotteen erikokoisten pakkausten keskimääräisten hävikkien välillä, Soygurt-tapaustutkimusta lukuun ottamatta. Toisaalta kuluttajakyselyn mukaan eniten ruokahävikkiä tuottavat taloudet pitivät pientä pakkauskokoa tärkeänä tapana vähentää ympäristövaikutuksia. Tutkimuksessa havaittiin, että kuluttajakyselyllä, on hyvin vaikeaa selvittää todellisen ruokahävikin määrää luotettavasti, varsinkaan erilaisten pakkausratkaisujen funktiona. Oletettaessa rinnakkaisten pakkausvaihtoehtojen kotitaloushävikit samoiksi, havaittiin kokonaisympäristövaikutusten erojen eri tuote-pakkausjärjestelmien välillä jäävän suhteellisen pieniksi.

\section{Kirjallisuus}

Katajajuuri, J.-M., Virtanen, Y., Voutilainen, P., Tuhkanen, H.-R., Kurppa, S. 2003. Elintarvikkeiden ympäristövaikutukset: FOODCHAIN. MMM:n julkaisuja 6: $64 \mathrm{~s}$.

Katajajuuri, J.-M. \& Virtanen, Y. 2007. Environmental Impacts of Product Packaging in Finnish Food Production Chains. Book of Proceedings, 5th International Conference LCA In Foods, 25 - 26 April 2007, Gothenburg, Sweden. The Swedish Institute for Food and Biotechnology s. 138-142.

Solomon, S., Qin, D., Manning, M., Alley, R.B., Berntsen, T., Bindoff, N.L., Chen, Z., Chidthaisong, A., Gregory, J.M., Hegerl, G.C., Heimann, M., Hewitson, B., Hoskins, B.J., Joos, F., Jouzel, J., Kattsov, V., Lohmann, U., Matsuno, T., Molina, M., Nicholls, N., Overpeck, J., Raga, G., Ramaswamy, V., Ren, J., Rusticucci, M., Somerville, R., Stocker, T.F., Whetton, P., Wood, R.A. ja Wratt, D. 2007 Climate Change 2007: The Physical Science Basis. Contribution of Working Group I to the Fourth Assessment Report of the Intergovernmental Panel on Climate Change. Cambridge University Press, Cambridge 2007.

Seppälä, J., Knuuttila, S. \& Silvo, K. 2004. Eutrophication of aquatic ecosystems. A new method for calculating the potential contributions of nitrogen and phosphorus. International Journal of Life Cycle Assessment Vol 9 No 2. 2004, s. 90-100.

Seppälä, J., Posch, M., Johansson, M. \& Hettelingh, J-P. 2006. Country-dependent characterisation factors for acidification and terrestrial eutrophication based on accumulated exceedence as an impact category indicator. International Journal of Life Cycle Assessment Vol 11 No 6. 2006, s. 403-416.

Silvenius, F., J.-M., Kaisa Grönman. Soukka, R., Koivupuro,, H.-K. \& Virtanen, Y. 2011. Role of packaging in food products. In Finkbeiner, M. (ed.) Towards life Cycle management. Springer Science + Business Media B.V. ISBN 978-94-007-1898-2, e-ISBN 978-94-007-1899-9. Osa 6, s. 359-370.

WRAP 2008 Waste and Resources Action Programme, WRAP, The Food We Waste 2008. 